\title{
Neuroprotective effects of selegiline on rat neural stem cells treated with hydrogen peroxide
}

\author{
ALIREZA ABDANIPOUR $^{1}$, IRAJ JAFARI ANARKOOLI ${ }^{1}$, SAEED SHOKRI $^{1}$, MEHRDAD GHORBANLOU $^{1}$, \\ VAHID BAYATI $^{2}$ and REZA NEJATBAKHSH ${ }^{1}$ \\ ${ }^{1}$ Department of Anatomical Sciences, School of Medicine, Zanjan University of Medical Sciences, \\ Zanjan 45139-56184; ${ }^{2}$ Cellular and Molecular Research Center, School of Medicine, \\ Ahvaz Jundishapur University of Medical Sciences, Ahvaz, Khuzestan 6135715794, Iran
}

Received September 12, 2017; Accepted October 24, 2017

DOI: $10.3892 /$ br.2017.1023

\begin{abstract}
Oxidative stress and reactive oxygen species generation have been implicated in the pathogenesis of several neurological disorders including Parkinson's disease, Alzheimer's disease, amyotrophic lateral sclerosis and multiple sclerosis. In the present study, the neuroprotective effects of selegiline against hydrogen peroxide-induced oxidative stress in hippocampus-derived neural stem cells (NSCs) were evaluated. NSCs isolated from neonatal Wistar rats were pretreated with different doses of selegiline for $48 \mathrm{~h}$ and then exposed to $125 \mu \mathrm{M} \mathrm{H}_{2} \mathrm{O}_{2}$ for $30 \mathrm{~min}$. Using MTT and terminal deoxynucleotidyl transferase-mediated dUTP nick end labeling assays, acridine orange/ethidium bromide staining and reverse transcription-quantitative polymerase chain reaction, the effects of selegiline on cell survival, apoptosis and the expression of B-cell lymphoma 2 (Bcl-2) and heat shock protein 4 (Hspa4) in pretreated stem cells were assessed compared with a control group lacking pretreatment. The results indicated that the viability of cells pretreated with $20 \mu \mathrm{M}$ selegiline was significantly increased compared with the control group $(\mathrm{P}<0.05)$. Additionally, $20 \mu \mathrm{M}$ selegiline increased the mRNA expression of Bcl-2 and Hspa4 ( $\mathrm{P}<0.05$ vs. control) and suppressed oxidative stress-induced cell death (apoptosis and necrosis; $\mathrm{P}<0.05$ vs. control and $10 \mu \mathrm{M}$ groups). From these findings, it was concluded that selegiline may be a therapeutic candidate for the treatment of neurological diseases mediated by oxidative stress.
\end{abstract}

\section{Introduction}

The most common neorodegenerative disorders, namely Alzheimer's disease (AD) and Parkinson's disease (PD), are

Correspondence to: Dr Reza Nejatbakhsh, Department of Anatomical Sciences, School of Medicine, Zanjan University of Medical Sciences, Mahdavi Blvd, Shahrak-e Karmandan, Zanjan 45139-56184, Iran E-mail:reza_nejat@yahoo.com

Key words: neural stem cells, selegiline, oxidative stress, B-cell lymphoma 2 , heat shock protein 4 prevalent in $\sim 1 \%$ of individuals aged 60 years and older (1). Their etiologies remain uncertain, though there are a number of established pathogenic factors, including oxidative stress, neural apoptosis, mitochondrial dysfunction, excitotoxicity, impairment of the ubiquitin-proteasome system and inflammation (2,3). Neuroprotective therapy has been suggested to prevent disease progression by inhibiting the action of pathogenic factors, for instance, by reducing the production of reactive oxygen species (ROS) (4). Overproduction of ROS may cause oxidative damage to biomolecules and subsequently DNA damage, ultimately leading to the development of neurodegenerative diseases. According to studies on PD, inhibitors of type B monoamine oxidase (MAO), including selegiline [also known as (-)-deprenyl] and rasagiline, are among the most promising neuroprotective agents identified to date (5-7). MAO exists in two forms, MAO-A and -B. The catalytic activity of these enzymes generates $\mathrm{H}_{2} \mathrm{O}_{2}$ and nitrogen species, which are toxic products that may cause oxidative damage to mitochondrial DNA (mtDNA) and thus have potential implications for apoptosis, aging and neurodegenerative processes (8). The MAO-B inhibitor, selegiline, is typically recommended as a first-line treatment for PD and has been demonstrated to possess neuroprotective functions (9); notably, this inhibitor protected neuronal cells against induced cell death in cellular and animal models $(10,11)$. The neuroprotective functions of selegiline have been attributed to stabilization of the mitochondria, to the prevention of death signaling processes, and to upregulation of the anti-apoptotic B-cell lymphoma 2 (Bcl-2) protein family and neurotrophic factors $(10,11)$. Previous studies have also indicated that MAO inhibitors suppress $\mathrm{H}_{2} \mathrm{O}_{2}$-induced oxidative stress and attenuate the induced cell injury by promoting expression of the Bcl-2 family $(10,11)$. Unlike other drugs with neuroprotective properties, selegiline and its metabolites are able to cross the blood-brain barrier, following which they exhibit highest accumulation in the thalamus, basal ganglia, mesencephalon and cingulate gyrus $(12,13)$.

As a follow-up to previous research by our group $(14,15)$, the present study investigated the in vitro therapeutic effects of selegiline on the apoptosis and survival of hippocampus-derived rat neural stem cells (NSCs) treated with hydrogen peroxide, namely through MTT and terminal deoxynucleotidyl 
transferase-mediated dUTP nick end labeling (TUNEL) assays and acridine orange/ethidium bromide staining, along with reverse transcription-quantitative polymerase chain reaction (RT-qPCR) to determine the expression of heat shock protein 4 (Hspa4) and Bcl-2.

\section{Materials and methods}

Isolation and expansion of NSCs. NSCs were isolated from the hippocampus of 5 neonatal Wistar rats (10 days old) purchased from the the Razi Vaccine and Serum Research Institute (Karaj, Iran) using a neurosphere assay as described previously (16). Prior to cell isolation, the rats were housed under a 12 -h light/dark cycle at $24^{\circ} \mathrm{C}$ and $30-35 \%$ humidity with food and water available ad libitum. NSCs were collected from the hippocampus of the rats under anesthesia with ketamine $(100 \mathrm{mg} / \mathrm{kg})$ and xylazine $(10 \mathrm{mg} / \mathrm{kg}$; intraperitoneal injection). The dissected hippocampi were washed in phosphate-buffered saline (PBS) supplemented with $4.5 \mathrm{~g} / \mathrm{l}$ glucose solution and then centrifuged for $5 \mathrm{~min}$ at $1,600 \mathrm{x} \mathrm{g}$ and $4^{\circ} \mathrm{C}$. The collected tissues in the pellet were dissociated for $30 \mathrm{~min}$ at room temperature (RT) using a digestion mixture of $2.5 \mathrm{U} / \mathrm{ml}$ papain (Sigma-Aldrich; Merck KGaA, Darmstadt, Germany), 40 U/ml dispase II (Sigma-Aldrich; Merck KGaA) and $400 \mathrm{U} / \mathrm{ml}$ accutase (Invitrogen; Thermo Fisher Scientific, Inc., Waltham, MA, USA), with mixing of the solution every $10 \mathrm{~min}$. Subsequently, the cell mixture was passed through a $70-\mu \mathrm{m}$ cell strainer and then centrifuged for $5 \mathrm{~min}$ at $800 \mathrm{x} \mathrm{g}$ and $4^{\circ} \mathrm{C}$. Following centrifugation, the pellets were resuspended in $1 \mathrm{ml}$ Dulbecco's modified Eagle's medium F-12 (DMEM/F12; Invitrogen; Thermo Fisher Scientific, Inc.). The isolated cells were seeded in a $25-\mathrm{cm}^{2}$ non-adherent plastic flask $\left(10^{5}\right.$ cells $\left./ \mathrm{ml}\right)$ in DMEM/F12 supplemented with $2 \%$ B27 supplement (Gibco; Thermo Fisher Scientific, Inc.), $20 \mathrm{ng} / \mathrm{ml}$ basic fibroblast growth factor (bFGF; Invitrogen; Thermo Fisher Scientific, Inc.), $20 \mathrm{ng} / \mathrm{ml}$ epidermal growth factor (EGF; Invitrogen; Thermo Fisher Scientific, Inc.), $100 \mathrm{U} / \mathrm{ml}$ penicillin and $100 \mathrm{mg} / \mathrm{ml}$ streptomycin and incubated at $37^{\circ} \mathrm{C}$ in $5 \% \mathrm{CO}_{2}$ for 1-2 weeks to enable neurosphere formation. The medium and growth factors were replenished every 2 days. Following this, floating neurospheres were collected by centrifugation at $300 \mathrm{x}$ g for $5 \mathrm{~min}$ at RT. They were then dissociated enzymatically using trypsin-EDTA $(0.25 \%)$ and mechanically (by pipetting) to single cells. The cells were then suspended in DMEM/F12 supplemented with $2 \%$ B27, $20 \mathrm{ng} / \mathrm{ml} \mathrm{bFGF,}$ $20 \mathrm{ng} / \mathrm{ml} \mathrm{EGF}$ and 5\% fetal bovine serum (Sigma-Aldrich; Merck $\mathrm{KGaA}$ ) for 1 week at $37^{\circ} \mathrm{C}$ and $5 \% \mathrm{CO}_{2}$ in 6 -well adherent plates $\left(5 \times 10^{6}\right.$ cells/well) coated with poly-l-lysine (Sigma-Aldrich; Merck KGaA) and passaged up to three times. Nestin as a neural stem/precursor cell marker (17) was evaluated immunocytochemically. The present study adhered to institutional guidelines for the care and use of laboratory animals, and all experimental procedures were reviewed and approved by the Ethics Committee for the Use of Experimental Animals at Tarbiat Modares University (Tehran, Iran).

Selegiline cell treatments. $\mathrm{H}_{2} \mathrm{O}_{2}$ was used to induce oxidative stress, and was prepared from $30 \%$ stock solution prior to each experiment. Third-passage NSCs were cultured in 96-well plates $\left(10^{5}\right.$ cells/well) in DMEM/F12 medium supplemented with $2 \% \mathrm{~B} 27,20 \mathrm{ng} / \mathrm{ml} \mathrm{bFGF}$ and $20 \mathrm{ng} / \mathrm{ml}$ EGF. The NSCs were then incubated at $37^{\circ} \mathrm{C}$ in $5 \% \mathrm{CO}_{2}$ with $125 \mu \mathrm{M} \mathrm{H}_{2} \mathrm{O}_{2}$ for $30 \mathrm{~min}$. To evaluate the neuroprotective effects of selegiline, cells were pretreated with different concentrations of selegiline (Sigma-Aldrich; Merck KGaA; 0, 10, 20, 30 and $40 \mu \mathrm{M}$ ) $48 \mathrm{~h}$ prior to the $\mathrm{H}_{2} \mathrm{O}_{2}$ treatment. NSCs without selegilin treatment $(0 \mu \mathrm{M})$ were used as a control group. The control cells were cultured in the above DMEM/F12 medium for $48 \mathrm{~h}$ at $37^{\circ} \mathrm{C}$, then treated with $125 \mu \mathrm{M} \mathrm{H}_{2} \mathrm{O}_{2}$ for $30 \mathrm{~min}$.

Immunostaining. The hippocampus-derived NSCs were cultured on cover slides $\left(5 \times 10^{3}\right.$ cells/slide) in the supplemented DMEM/F12 (2\% B27, $20 \mathrm{ng} / \mathrm{ml} \mathrm{bFGF}$ and $20 \mathrm{ng} / \mathrm{ml}$ EGF) for $48 \mathrm{~h}$ at $37^{\circ} \mathrm{C}$ in $5 \% \mathrm{CO}_{2}$, then fixed in $3 \%$ paraformaldehyde for $20 \mathrm{~min}$ at RT. The cells were then permeabilized in $100 \%$ methanol for $30 \mathrm{~min}$ at RT to enable antibody-antigen interaction. For immunofluorescence, the cells were incubated with anti-nestin monoclonal antibodies, (1:200; ab6142; Abcam, Cambridge, $\mathrm{UK}$ ) for $2 \mathrm{~h}$ at $4^{\circ} \mathrm{C}$, then with fluorescein isothiocyanate-conjugated rabbit anti-mouse antibody (1:300; ab6724; Abcam) for $2 \mathrm{~h}$ at RT. Nuclei were counterstained with ethidium bromide for $1 \mathrm{~min}$ at RT to visualize the nuclei. Following staining, cells were examined using an inverted fluorescence microscope and the number of immunopositive cells were counted in a minimum of 100 cells per experiment. Corresponding negative controls were established using secondary antibodies without primary antibody incubation, to exclude nonspecific binding of secondary antibody to the sample.

Viability assay. Cell viability was evaluated using an MTT bromide assay, as described previously (18). Cells were treated with $125 \mu \mathrm{M} \mathrm{H}_{2} \mathrm{O}_{2}$ and different concentrations of selegiline $48 \mathrm{~h}$ before the $\mathrm{H}_{2} \mathrm{O}_{2}$ treatment. The treated cells were incubated with $1 \mathrm{mg} / \mathrm{ml} \mathrm{MTT} \mathrm{(Sigma} \mathrm{Aldrich;} \mathrm{Merck} \mathrm{KGaA)} \mathrm{for}$ $4 \mathrm{~h}$, after which the culture medium (DMEM/F12 with $2 \%$ B27, $20 \mathrm{ng} / \mathrm{ml} \mathrm{bFGF}$ and $20 \mathrm{ng} / \mathrm{ml} \mathrm{EGF)} \mathrm{was} \mathrm{removed} \mathrm{and}$ $100 \mu \mathrm{l}$ dimethyl sulfoxide was added to each well to dissolve the formazan crystals. The quantity of formazan dissolved was quantified from absorbance at $570 \mathrm{~nm}$ (A570) using a microplate ELISA reader, and relative cell viability (\%) was calculated as follows: (A570 of treated samples/A570 of controls) x $100(19,20)$.

TUNEL detection of apoptotic cells. Following treatment, the NSCs were fixed with 4\% paraformaldehyde in PBS for $30 \mathrm{~min}$ at RT. The cells were subjected to a TUNEL assay using an In-Situ Cell Death Detection kit (Roche Applied Science, Penzberg, Germany) according to the manufacturer's instructions. TUNEL-positive cells were labeled using diaminobenzidine as the chromogen for 3-7 min at RT, and counterstained with hematoxylin for $5 \mathrm{~min}$ at RT. The percentage of TUNEL-positive cells was assessed using an Olympus phase contrast fluorescence microscope (Olympus Corporation, Tokyo, Japan) in five randomly selected fields for each well.

Acridine orangelethidium bromide staining. Necrotic morphological changes in the treated cells were assessed by acridine orange/ethidium bromide staining. Following the selegiline and $\mathrm{H}_{2} \mathrm{O}_{2}$ treatments, the NSCs were washed with 
Table I. Primer sequences.

\begin{tabular}{lcll}
\hline Gene & GenBank accession no. & \multicolumn{1}{c}{ Forward, 5'-3' } & \multicolumn{1}{c}{ Reverse, $5^{\prime}-3^{\prime}$} \\
\hline B2M & NM_012512.2 & CTTGCCATTCAGAAAACTCC & CATCGGTCTCGGTGGGTG \\
Bcl-2 & NM_016993 & ACGGTGGTGGAGGAACTCTTCAGG & AATCAAACAGAGGTCGCATGCTGG \\
Hspa4 & NM_153629 & GAGTGCGAATGCTTCAGACCTCCC & CGTGTGGCTCCACCAACTATCTCC
\end{tabular}

Primers were designed with Gene Runner 3.05 software (produced by info@genfanavaran.com). B2M, $\beta 2$-microglobulin; Bcl-2, B-cell lymphoma 2; Hspa4, heat shock protein 4.

PBS buffer and fixed with $4 \%$ paraformaldehyde for $15 \mathrm{~min}$ at RT, then stained with acridine orange/ethidium bromide (Sigma-Aldrich; Merck KGaA; $100 \mu \mathrm{g} / \mathrm{ml}$ of each) for $5 \mathrm{~min}$ at RT. The number of necrotic cells, identified by orange/yellow cytoplasmic staining and by non-condensed chromatin and/or non-fragmented nuclei (21), were counted in a total of 200 cells. The cells were observed using a fluorescence microscope.

$R T-q P C R$. RT-qPCR was performed with cDNA obtained from the 0 (control) and $20 \mu \mathrm{M}$ selegiline groups following induced oxidative stress. A total of 1,000 ng purified RNA obtained from cultured cells with TRIzol (Invitrogen; Thermo Fisher Scientific, Inc.) was used to synthesize $20 \mu \mathrm{l}$ cDNA using a RevertAid $^{\mathrm{TM}}$ First Strand cDNA Synthesis kit (Fermentas, Germany) according to the manufacturer's instructions. The cDNA was used to quantify Bcl-2 and Hspa4 mRNA levels, with $\beta 2$-microglobulin (B2M) used as an internal control for normalization. The primer sequences of all primers used are listed in Table I. The PCR reaction was performed in a $25-\mu 1$ final reaction volume [containing forward and reverse primers (200 nM each), cDNA $(0.5 \mu \mathrm{l}), \mathrm{SYBR}^{\circledR}$-Green I (12.5 $\mu \mathrm{l}$; Fermentas; Thermo Fisher Scientific, Inc.) and nuclease-free water up to final volume] for 40 cycles at $95^{\circ} \mathrm{C}$ for $15 \mathrm{sec}$ followed by $60^{\circ} \mathrm{C}$ for $1 \mathrm{~min}$. Relative changes in target mRNA levels were determined using the $\Delta \Delta \mathrm{C}_{\mathrm{q}}$ method (22).

Statistical analysis. Data analysis was performed using SPSS 15.0 software (SPSS, Inc., Chicago, IL, USA). All data are presented as the mean \pm standard error of the mean from 5 independent experiments. To compare differences between the means of multiple groups, one-way analysis of variance followed by Tukey's post hoc test was used. $\mathrm{P}<0.05$ was considered to indicate statistical significance.

\section{Results}

Generation of NSCs. The results of the primary culture of hippocampus-derived NSCs are presented in Fig. 1A-D. Following NSC isolation and culture, single cells were observed to form primary neurospheres by day 7 (Fig. 1A). Secondary neurospheres originated from the primary neurospheres, and a homogeneous adherent NSC population was obtained after 3 passages (Fig. 1B). The majority of isolated cells $(98.71 \pm 0.29 \%)$ exhibited positive staining for nestin marker (Fig. 1D), indicating successful isolation of NSCs, and negative controls incubated in the absence of primary antibody confirmed the specificity of labeling (data not shown).
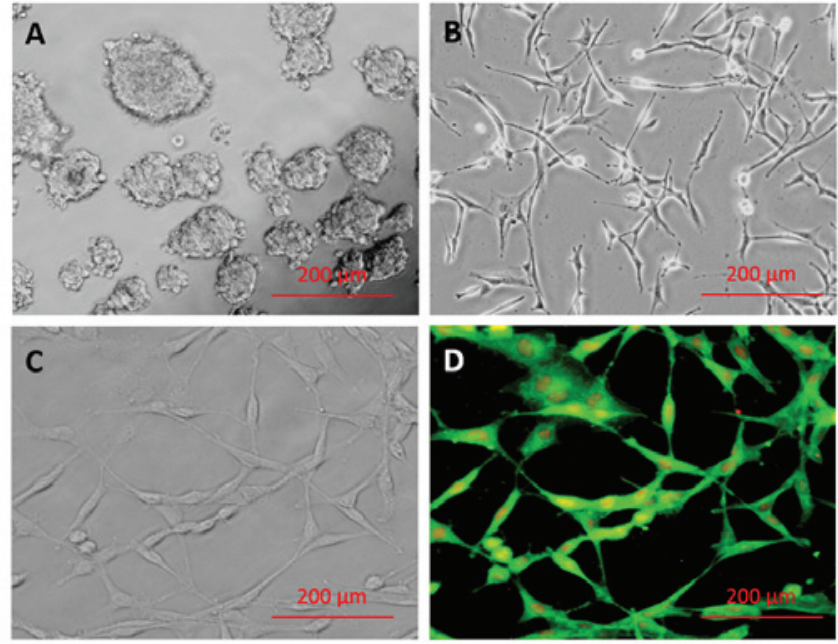

Figure 1. Representative photomicrographs of hippocampus-derived NSCs. (A) Floating neurospheres derived from rat hippocampus after culture for 7 days. (B) Hippocampus-derived NSCs at passage 3. (C) Phase contrast micrograph and (D) immunostaining of nestin (green) in the same field. Nuclei were counterstained with ethidium bromide (red). Magnification, x200. NSC, neural stem cell.

Neuroprotective effect of selegiline on NSC viability. An MTT assay was performed to determine the neuroprotective effect of increasing concentrations of selegiline $(0-40 \mu \mathrm{M})$ against oxidative stress induced by $125 \mu \mathrm{M} \mathrm{H}_{2} \mathrm{O}_{2}$. The attained values were normalized based on values of NSCs without any treatment (negative control group). As depicted in Fig. 2A, pretreatment with $20 \mu \mathrm{M}$ selegiline for $48 \mathrm{~h}$ caused an increase in the percentage of viable cells $(64.4 \pm 2.17 \%)$ compared with the $0(29.66 \pm 2.04 \% ; \mathrm{P}<0.05)$ and $10 \mu \mathrm{M}(58.44 \pm 6.60 \%)$ selegiline groups. However, further increases in selegiline concentration caused a decline in cell viability compared with the $20 \mu \mathrm{M}$ selegiline group, which was deemed to be significant for $40 \mu \mathrm{M}(44.94 \pm 2.94 \%$; $\mathrm{P}<0.05)$.

Neuroprotective effect of selegiline on NSC survival. A TUNEL assay and acridine orange/ethidium bromide staining were performed to assess the pro-survival effects of selegiline in hippocampus-derived NSCs treated with increasing concentrations of selegiline for $48 \mathrm{~h}$ followed by $\mathrm{H}_{2} \mathrm{O}_{2}$ exposure. The TUNEL and necrotic cell staining indicated that $\mathrm{H}_{2} \mathrm{O}_{2}$ induced apoptotic and necrotic cell death (Fig. 2A-E). As depicted in Fig. 2A, pretreatment with $20 \mu \mathrm{M}$ selegiline caused significant decreases in the percentages of apoptotic $(30.10 \pm 1.48 \%)$ and necrotic $(27.32 \pm 2.68 \%)$ cells compared 


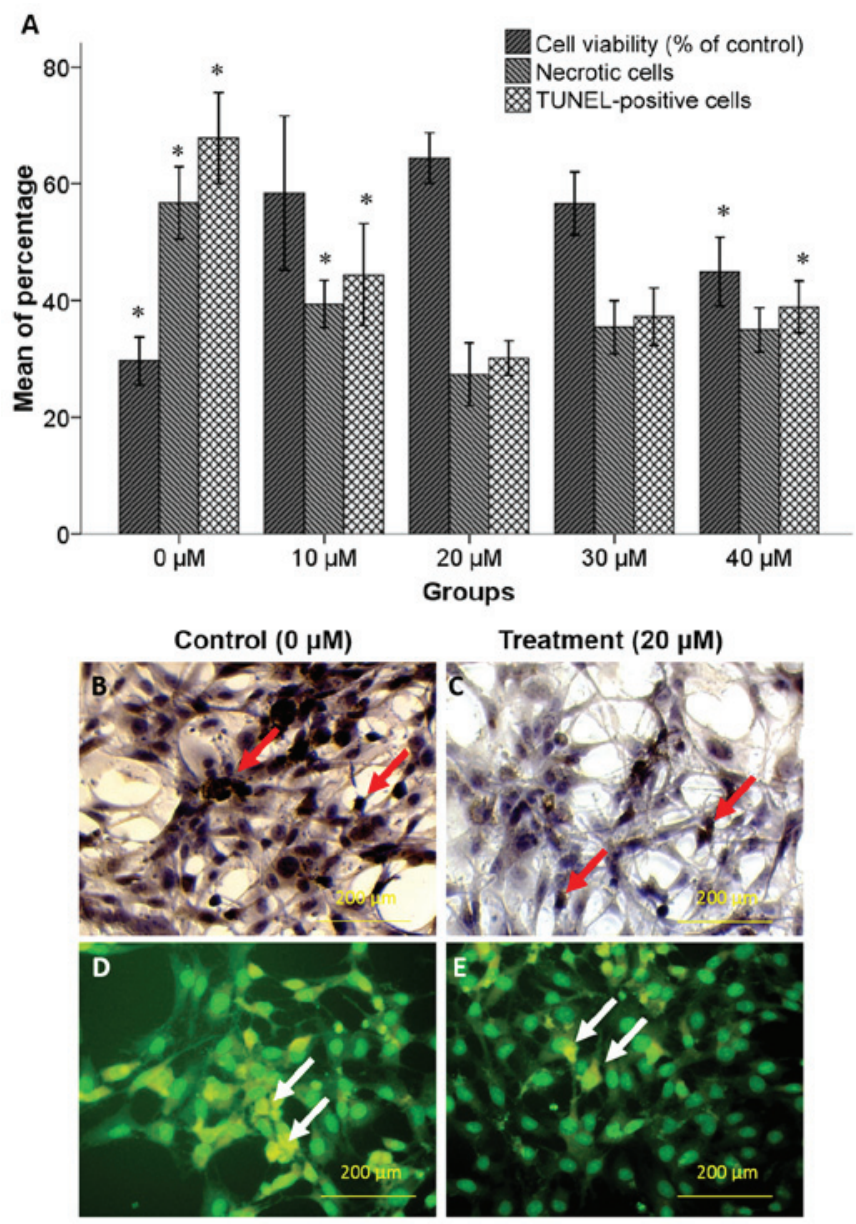

Figure 2. Effect of selegiline on cell viability, apoptosis and necrosis. (A) Mean percentages of viable, apoptotic and necrotic cells (relative to untreated cells) determined by MTT assay, TUNEL and acridine orange/ethidium bromide staining, respectively, following $125 \mu \mathrm{M} \mathrm{H}_{2} \mathrm{O}_{2}$ exposure with selegiline pretreatment. (B-E) Representative TUNEL and acridine orange staining images of NSCs at (B and D) 0 and (C and E) $20 \mu \mathrm{M}$ selegiline followed by $125 \mu \mathrm{M} \mathrm{H}_{2} \mathrm{O}_{2}$ exposure. Red arrows indicate DNA fragmentation. Late necrotic NSCs exhibited orange/red staining in non-condensed, non-fragmented nuclei (white arrows). Counterstaining with hematoxylin is shown in blue. Magnification, x200. The bars indicate the mean \pm standard error of the mean. ${ }^{*} \mathrm{P}<0.05$ vs. $20 \mu \mathrm{M}$ group. NSC, neural stem cell; TUNEL, terminal deoxynucleotidyl transferase-mediated dUTP nick end labeling.

with the $10 \mu \mathrm{M}$ selegiline group $(44.4 \pm 4.39$ and $39.37 \pm 2.01 \%$, respectively; $\mathrm{P}<0.05)$ and the $0 \mu \mathrm{M}$ (control) group $(67.84 \pm 3.91$ and $59.74 \pm 3.07 \%$, respectively; $\mathrm{P}<0.05$ ). However, further increases in selegiline concentration caused increased rates of cell apoptosis and necrosis compared with the $20 \mu \mathrm{M}$ selegiline group, which was deemed to be significant at $40 \mu \mathrm{M}$ on cell apoptosis $(33.89 \pm 2.21 \%$; $\mathrm{P}<0.05)$.

Effect of selegiline on Bcl-2 and Hspa4 expression. Increased levels of Bcl-2 and Hspa4 mRNA in $\mathrm{H}_{2} \mathrm{O}_{2}$-induced NSCs pretreated with $20 \mu \mathrm{M}$ selegiline for $48 \mathrm{~h}$ were confirmed by RT-qPCR (Fig. 3). Notably, following normalization to the expression of B2M, it was observed that the mRNA levels of Bcl-2 and Hspa4 were significantly increased in the $20 \mu \mathrm{M}$ selegiline group (2.90 \pm 0.05 and $1.18 \pm 0.03$, respectively) compared with the control group $(1.01 \pm 0.11$ and $0.77 \pm 0.02$, respectively; $\mathrm{P}<0.05$ ).

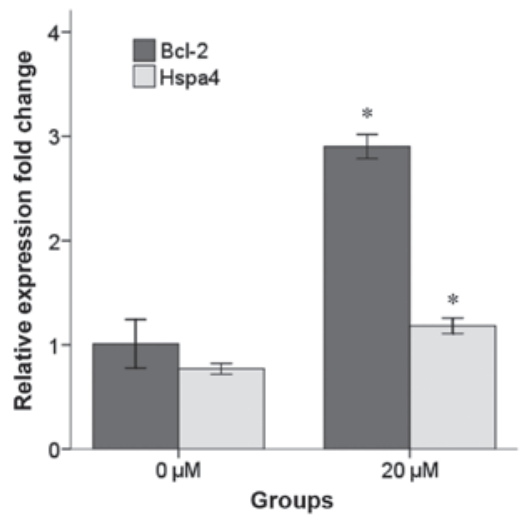

Figure 3. Fold changes in Bcl-2 and Hspa4 mRNA expression in $\mathrm{H}_{2} \mathrm{O}_{2}$-induced NSCs treated with $20 \mu \mathrm{M}$ selegiline. The results of polymerase chain reaction were presented as relative expression normalized to $\beta 2$-microglobulin mRNA amplification. The bars indicate the mean \pm standard error of the mean. ${ }^{*} \mathrm{P}<0.05$ vs. $20 \mu \mathrm{M}$ group. Bcl-2, B-cell lymphoma 2; Hspa4, heat shock protein 4; NSC, neural stem cell.

\section{Discussion}

In the present study, it was demonstrated that selegiline increased $\mathrm{Bcl}-2$ and Hspa4 mRNA expression in hippocampus-derived NSCs, and protected the cells against $\mathrm{H}_{2} \mathrm{O}_{2}$-induced apoptosis and necrosis. It has previously been reported that free radicals serve a causal role in biomolecular damage and neuronal cell death following oxidative stress $(2,23)$. In neurodegenerative disorders, a reduction of oxidative stress may attenuate apoptotic cell death and disease progression (24). MAO serves important roles in the generation of $\mathrm{H}_{2} \mathrm{O}_{2}$ and nitrogen species, and in apoptosis, aging and neurodegenerative processes $(8,25)$. Furthermore, increased levels of MAO-B mRNA and enzymatic activity have been observed in neurodegenerative diseases including PD (26).

In vitro and in vivo experiments have demonstrated that selegiline is a potent inhibitor of MAO-B and also enhances the synthesis of neurotrophic factors including glial cell-derived neurotrophic factor and brain-derived neurotrophic factor $(9,27,28)$. As a selective MAO-B inhibitor, selegiline may be used as an anti-PD drug to exert antioxidant and anti-apoptotic effects $(29,30)$. It has also been indicated that selegiline decreases oxidative stress and cell death induced by 1-methyl-4-phenylpyridinium $\left(\mathrm{MPP}^{+}\right)$, an inducing agent of PD (31). However, the protective effect of selegiline against $\mathrm{MPP}^{+}$-induced neuronal cell degeneration may be opposing dependent on concentration; while micromolar to submillimolar doses of selegiline promoted increased cell viability, concentrations of selegiline greater than $1 \mathrm{mM}$ induced a decrease in cell viability in the $\mathrm{MPP}^{+}$-treated cells (32). This opposing effect of selegiline regarding anti-apoptotic activity has also been demonstrated in A-2058 human melanoma cell culture, in which selegiline at a concentration range of $10^{-7}-10^{-3} \mathrm{M}$ caused significant inhibition of apoptosis, while treatment $10^{-3} \mathrm{M}$ selegiline caused $50 \%$ apoptosis after treatment for $72 \mathrm{~h}$ (29). The current results are in accordance with these previous studies.

The MAO-B inhibitors, rasagiline and selegiline, protect neuronal cells through upregulation of the pro-survival protein Bcl-2 and neurotrophic factors (33). In the present study, 
increases in the mRNA levels of Bcl-2 and Hspa4 were identified in hippocampal NSCs following treatment with $20 \mu \mathrm{M}$ selegiline for $48 \mathrm{~h}$. The Bcl-2 protein family controls the release of cytochrome $c(\mathrm{Cyt}-c)$ from the mitochondria and consists of pro-apoptotic (Bcl-2-associated $\mathrm{X}$ protein, $\mathrm{Bcl}-2$ homologous antagonist/killer, BH3 interacting-domain death agonist, Bcl-2-associated death promoter) and anti-apoptotic [Bcl-2, Bcl-extra large (Bcl-xL)] members (34). The primary function of anti-apoptotic Bcl-2 is to suppress mitochondrial Cyt- $c$ release, by regulating physiological membrane permeability, $\mathrm{Ca}^{2+}$ release and oxidative stress in the mitochondria $(35,36)$. Specific regions of Bcl-2, namely the Bcl-2 homology-3 and -4 domains, exert anti-apoptotic effects in in vivo and in vitro models $(37,38)$. Additionally, overexpression of $\mathrm{Bcl}-2$ protein has been documented to reduce tissue damage in animal models of PD $(39,40)$ and ischemia $(41,42)$, and protects cells against apoptosis (43). Furthermore, Bcl-2 overexpression prevented Cyt- $c$ release following peroxynitrite-induced apoptotic signaling, indicating the potential of Bcl-2 as a neuroprotective agent (44). In a previous study, selegiline increased the mRNA and protein levels of Bcl-2 and Bcl-xL in SH-SY5Y cells (45), but not in MAO-B-containing Caco-2 and U118MG cells $(46,47)$. These studies are consistent with present findings regarding the significant upregulation of Bcl-2 and improved survival of NSCs in response to $20 \mu \mathrm{M}$ selegiline.

Interestingly, it has been reported that $\mathrm{Hspa} 4$ may decrease the protein degradation and increase the stability of Bcl-2 during oxidative stress, and that an association may exist between Bcl-2 and the anti-apoptotic effect of Hspa4 (48). In consideration of the increases in Bcl-2 and Hspa4 mRNA and the potential role of $\mathrm{Bcl}-2$ in the selegiline-treated group, the current study indicated that these factors may have been associated with the decreased percentages of necrotic and TUNEL-positive cells decreased in the $20 \mu \mathrm{M}$ selegiline group compared with the 0 (control) and $10 \mu \mathrm{M}$ groups.

In conclusion, the current data suggested that selegiline is effective in protecting NSCs against oxidative stress. Therefore, selegiline may be considered as a drug candidate for neurological disorders in which oxidative stress serves an important role in pathogenesis.

\section{Acknowledgements}

The authors would like to thank Dr Saeid Hashamein from the Stem Cell Laboratory of Islamic Azad University for assisting with the research. The study was partly funded by Islamic Azad University, Ardabil Branch (grant no. 91.502).

\section{References}

1. DeMaagd G and Philip A: Parkinson's disease and its management: Part 1: Disease entity, risk factors, pathophysiology, clinical presentation, and diagnosis. PT 40: 504-532, 2015.

2. Uttara B, Singh AV, Zamboni P and Mahajan RT: Oxidative stress and neurodegenerative diseases: A review of upstream and downstream antioxidant therapeutic options. Curr Neuropharmacol 7: 65-74, 2009.

3. Guo C, Sun L, Chen X and Zhang D: Oxidative stress, mitochondrial damage and neurodegenerative diseases. Neural Regen Res 8: 2003-2014, 2013.

4. Sarkar S, Raymick J and Imam S: Neuroprotective and therapeutic strategies against Parkinson's disease: Recent Perspectives. Int J Mol Sci 17: 17, 2016.
5. Nayak L and Henchcliffe C: Rasagiline in treatment of Parkinson's disease. Neuropsychiatr Dis Treat 4: 23-32, 2008.

6. Riederer P and Laux G: MAO-inhibitors in Parkinson's disease. Exp Neurobiol 20: 1-17, 2011.

7. Bonneh-Barkay D, Ziv N and Finberg JP: Characterization of the neuroprotective activity of rasagiline in cerebellar granule cells. Neuropharmacology 48: 406-416, 2005.

8. Lu D, Johnson C, Johnson S, Tazik S and Ou XM: The neuroprotective effect of antidepressant drug via inhibition of TIEG2-MAO B mediated cell death. Drug Discov Ther 2: 289-295, 2008.

9. Zhao Q, Cai D and Bai Y: Selegiline rescues gait deficits and the loss of dopaminergic neurons in a subacute MPTP mouse model of Parkinson's disease. Int J Mol Med 32: 883-891, 2013.

10. Hara MR, Thomas B, Cascio MB, Bae BI, Hester LD, Dawson VL, Dawson TM, Sawa A and Snyder SH: Neuroprotection by pharmacologic blockade of the GAPDH death cascade. Proc Natl Acad Sci USA 103: 3887-3889, 2006.

11. Maruyama W, Akao Y, Carrillo MC, Kitani K, Youdium MB and Naoi M: Neuroprotection by propargylamines in Parkinson's disease: Suppression of apoptosis and induction of prosurvival genes. Neurotoxicol Teratol 24: 675-682, 2002.

12. Lecht S, Haroutiunian S, Hoffman A and Lazarovici P: Rasagiline - a novel MAO B inhibitor in Parkinson's disease therapy. Ther Clin Risk Manag 3: 467-474, 2007.

13. Fowler JS, Volkow ND, Logan J, Schlyer DJ, MacGregor RR, Wang GJ, Wolf AP, Pappas N, Alexoff D and Shea C: Monoamine oxidase B (MAO B) inhibitor therapy in Parkinson's disease: The degree and reversibility of human brain MAO B inhibition by Ro 19 6327. Neurology 43: 1984-1992, 1993.

14. Abdanipour A, Tiraihi T and Delshad A: Trans-differentiation of the adipose tissue-derived stem cells into neuron-like cells expressing neurotrophins by selegiline. Iran Biomed J 15: 113-121, 2011.

15. Abdanipour A and Tiraihi T: Induction of adipose-derived stem cell into motoneuron-like cells using selegiline as preinducer. Brain Res 1440: 23-33, 2012.

16. Abdanipour A, Sagha M, Noori-Zadeh A, Pakzad I and Tiraihi T: In vitro study of the long-term cortisol treatment effects on the growth rate and proliferation of the neural stem/precursor cells. Neurol Res 37: 117-124, 2015.

17. Suzuki S, Namiki J, Shibata S, Mastuzaki Y and Okano H: The neural stem/progenitor cell marker nestin is expressed in proliferative endothelial cells, but not in mature vasculature. J Histochem Cytochem 58: 721-730, 2010.

18. Gu J, Chi M, Sun X, Wang G, Li M, Liu L and Li X: Propofol-induced protection of SH-SY5Y cells against hydrogen peroxide is associated with the HO-1 via the ERK pathway. Int J Med Sci 10: 599-606, 2013

19. Han J, Talorete TP, Yamada P and Isoda H: Anti-proliferative and apoptotic effects of oleuropein and hydroxytyrosol on human breast cancer MCF-7 cells. Cytotechnology 59: 45-53, 2009.

20. Abdanipour A, Noori-Zadeh A, Mesbah-Namin SA, Bakhtiyari S, Nejatbakhsh R and Anarkooli IJ: Di-(2-ethylhexyl) phthalate-induced hippocampus-derived neural stem cells proliferation. Cell J 19: 166-172, 2017.

21. Didenko VV, Ngo H and Baskin DS: Early necrotic DNA degradation: Presence of blunt-ended DNA breaks, 3 ' and 5' overhangs in apoptosis, but only $5^{\prime}$ overhangs in early necrosis. Am J Pathol 162: 1571-1578, 2003.

22. Yuan JS, Reed A, Chen F and Stewart CN Jr: Statistical analysis of real-time PCR data. BMC Bioinformatics 7: 85, 2006.

23. Emerit J, Edeas M and Bricaire F: Neurodegenerative diseases and oxidative stress. Biomed Pharmacother 58: 39-46, 2004.

24. Ischiropoulos $\mathrm{H}$ and Beckman JS: Oxidative stress and nitration in neurodegeneration: Cause, effect, or association? J Clin Invest 111: 163-169, 2003.

25. Shih JC, Chen K and Ridd MJ: Monoamine oxidase: From genes to behavior. Annu Rev Neurosci 22: 197-217, 1999.

26. Jakubauskiene E, Janaviciute V, Peciuliene I, Söderkvist P and Kanopka A: G/A polymorphism in intronic sequence affects the processing of MAO-B gene in patients with Parkinson disease. FEBS Lett 586: 3698-3704, 2012.

27. Youdim MB, Gross A and Finberg JP: Rasagiline [N-propargyl$1 \mathrm{R}(+)$-aminoindan], a selective and potent inhibitor of mitochondrial monoamine oxidase B. Br J Pharmacol 132: 500-506, 2001.

28. Nagatsu T and Sawada M: Molecular mechanism of the relation of monoamine oxidase B and its inhibitors to Parkinson's disease: Possible implications of glial cells. J Neural Transm Suppl 71: 53-65, 2006. 
29. Magyar K and Szende B: (-)-Deprenyl, a selective MAO-B inhibitor, with apoptotic and anti-apoptotic properties. Neurotoxicology 25: 233-242, 2004.

30. Tsao CM, Jhang JG, Chen SJ, Ka SM, Wu TC, Liaw WJ, Huang $\mathrm{HC}$ and $\mathrm{Wu} \mathrm{CC}$ : Adjuvant potential of selegiline in attenuating organ dysfunction in septic rats with peritonitis. PLoS One 9: e108455, 2014.

31. Dias V, Junn E and Mouradian MM: The role of oxidative stress in Parkinson's disease. J Parkinsons Dis 3: 461-491, 2013.

32. Chetsawang B, Kooncumchoo P, Govitrapong P and Ebadi M: 1-Methyl-4-phenyl-pyridinium ion-induced oxidative stress c-Jun phosphorylation and DNA fragmentation factor-45 cleavage in SK-N-SH cells are averted by selegiline. Neurochem Int 53: 283-288, 2008.

33. Inaba-Hasegawa K, Akao Y, Maruyama W and Naoi M Rasagiline and selegiline, inhibitors of type B monoamine oxidase, induce type A monoamine oxidase in human SH-SY5Y cells. J Neural Transm (Vienna) 120: 435-444, 2013.

34. Gillies LA and Kuwana T: Apoptosis regulation at the mitochondrial outer membrane. J Cell Biochem 115: 632-640, 2014.

35. Shacka JJ and Roth KA: Regulation of neuronal cell death and neurodegeneration by members of the Bcl-2 family: Therapeutic implications. Curr Drug Targets CNS Neurol Disord 4: 25-39, 2005.

36. Schwartz PS and Hockenbery DM: Bcl-2-related survival proteins. Cell Death Differ 13: 1250-1255, 2006.

37. Shimizu S, Konishi A, Kodama T and Tsujimoto Y: BH4 domain of antiapoptotic Bcl-2 family members closes voltage-dependent anion channel and inhibits apoptotic mitochondrial changes and cell death. Proc Natl Acad Sci USA 97: 3100-3105, 2000.

38. Malik JM, Shevtsova Z, Bähr M and Kügler S: Long-term in vivo inhibition of CNS neurodegeneration by Bcl-XL gene transfer. Mol Ther 11: 373-381, 2005.

39. Offen D, Beart PM, Cheung NS, Pascoe CJ, Hochman A, Gorodin S, Melamed E, Bernard R and Bernard O: Transgenic mice expressing human $\mathrm{Bcl}-2$ in their neurons are resistant to 6-hydroxydopamine and 1-methyl-4-phenyl-1,2,3,6- tetrahydropyridine neurotoxicity. Proc Natl Acad Sci USA 95: 5789-5794, 1998.
40. Natsume A, Mata M, Goss J, Huang S, Wolfe D, Oligino T, Glorioso J and Fink DJ: Bcl-2 and GDNF delivered by HSV-mediated gene transfer act additively to protect dopaminergic neurons from 6-OHDA-induced degeneration. Exp Neurol 169: 231-238, 2001.

41. Cao YJ, Shibata T and Rainov NG: Liposome-mediated transfer of the bcl-2 gene results in neuroprotection after in vivo transient focal cerebral ischemia in an animal model. Gene Ther 9: 415-419, 2002

42. Nuydens R, Dispersyn G, Van Den Kieboom G, de Jong M, Connors R, Ramaekers F, Borgers M and Geerts $\mathrm{H}$ : Bcl-2 protects neuronal cells against taxol-induced apoptosis by inducing multi-nucleation. Apoptosis 5: 335-343, 2000.

43. Nuydens R, Dispersyn G, Van Den Keiboom G, de Jong M, Connors R, Ramaekers F, Borgers M and Geerts H: Bcl-2 protects against apoptosis-related microtubule alterations in neuronal cells. Apoptosis 5: 43-51, 2000.

44. Yang J, Liu X, Bhalla K, Kim CN, Ibrado AM, Cai J, Peng TI, Jones DP and Wang X: Prevention of apoptosis by Bcl-2: Release of cytochrome c from mitochondria blocked. Science 275: 1129-1132, 1997.

45. Naoi M,Maruyama W, Akao Y, Yi H and Yamaoka Y: Involvement of type A monoamine oxidase in neurodegeneration: Regulation of mitochondrial signaling leading to cell death or neuroprotection. J Neural Transm Suppl 71: 67-77, 2006.

46. Naoi M, Maruyama W and Inaba-Hasegawa K: Type A and B monoamine oxidase in age-related neurodegenerative disorders: Their distinct roles in neuronal death and survival. Curr Top Med Chem 12: 2177-2188, 2012.

47. Chiou SH, Ku HH, Tsai TH, Lin HL, Chen LH, Chien CS, Ho LL, Lee CH and Chang YL: Moclobemide upregulated Bcl-2 expression and induced neural stem cell differentiation into serotoninergic neuron via extracellular-regulated kinase pathway. $\mathrm{Br}$ J Pharmacol 148: 587-598, 2006.

48. Jiang B, Liang P, Deng G, Tu Z, Liu M and Xiao X: Increased stability of Bcl-2 in HSP70-mediated protection against apoptosis induced by oxidative stress. Cell Stress Chaperones 16: 143-152, 2011. 